Original Research Paper

\title{
Penanggulangan Banjir melalui Reboisasi sebagai Bentuk Pemberdayaan Masyarakat Guna Mewujudkan Desa Siaga Bencana
}

\author{
I Wayan Merta ${ }^{1 *}$, I Wayan Mudiarsa Darmanika2, Rauh Jaril Gifari3 \\ ${ }^{1}$ Program Studi Pendidikan Biologi, Universitas Mataram, Mataram Indonesia; \\ ${ }^{2}$ Program Studi Pendidikan Guru Sekolah Dasar, Universitas Mataram, Mataram Indonesia; \\ ${ }^{3}$ Program Studi Pendidikan Guru Sekolah Dasar, Universitas Mataram, Mataram Indonesia
}

https://doi.org/10.29303/jpmpi.v3i2.1415

Sitasi: Merta, I. W., Darmanika, I. W. M \& Gifari, R. J. (2022). Penanggulangan Banjir melalui Reboisasi sebagai Bentuk Pemberdayaan Masyarakat Guna Mewujudkan Desa Siaga Bencana. Jurnal Pengabdian Magister Pendidikan IPA, 5(1)

\section{Article history}

Received: 10 Januari 2022

Revised: 01 Februari 2022

Accepted: 05 Februari 2022

*Corresponding Author: I

Wayan Merta Program

Studi Pendidikan Biologi,

Universitas Mataram,

Mataram Indonesia; Email:

wayanmerta.fkip@unram.ac.id

\begin{abstract}
Perubahan penggunaan lahan menjadi pemukiman dan lahan pertanian menyebabkan air hujan yang jatuh tidak langsung menembus tanah. Kawasan di Desa Taman Baru Sekotong merupakan kawasan yang landai sehingga potensi banjir dan erosi di kawasan ini cukup tinggi. Upaya konservasi tanah dan air melalui gerakan penanaman pohon yang melibatkan masyarakat merupakan upaya strategis untuk mengurangi bahaya erosi dan mengalirkan air hujan ke dalam tanah melalui proses peresapan. Kegiatan ini dilaksanakan pada bulan november 2021 dan dipusatkan di Desa Taman Baru. Metode pengabdian yang digunakan berupa pendampingan masyarakat, analisis dan evaluasi penanaman pohon dan pembersihan sungai. Kegiatan penanaman pohon ini disambut antusias oleh komponen masyarakat. Terdapat sekitar 150 bibit pohon yang ditanam di sekitar sungai Dusun Taman Sejati.
\end{abstract}

Keywords: Banjir, Penanaman Pohon, Erosi

\section{Pendahuluan}

Perguruan Tinggi harus mempersiapkan mahasiswa untuk berkontribusi di tengah-tengah masyarakat secara profesional, salah satunya dengan melakukan program Kuliah Kerja Nyata (KKN) yaitu pengabdian mahasiswa di masyarakat. KKN Terpadu merupakan kolaborasi yang didukung oleh Pemerintahan daerah dan masyarakat desa dalam menanggulangi permasalahan yang kerap muncul di sekitar aliran sungai di Desa Taman Baru. Salah satu wilayah yang dilalui sungai Dusun Timbal adalah daerah yang sangat berperan penting sebagai penangkal bencana seperti banjir dan tanah longsor di wilayah daerah aliran sungai. Luas wilayah hutan di daerah aliran sungai sudah semakin bertambah dari tahun ketahun sejak 5 tahun terakhir .

Desa Taman Baru, Kecamatan Sekotong termasuk dalam daerah berpotensi tanah longsor dengan resiko rendah berdasarkan analisis. Daerah zonasi resiko longsor di dusun Taman Sejati seluas 250 hektar sepanjang $8 \mathrm{KM}$. Taman sejati memiliki 2 Iklim, kemarau dan penghujan dan mempunyai pengaruh langsung terhadap pola tanam yang ada di Desa Taman Baru Kecamatan Sekotong (Ahmad Tanwir, 2021). Wilayah Desa Taman Sejati menjadi wilayah yang berpotensi longsor paling tinggi jika dibandingkan dengan desa lain. Selain itu Desa Taman Baru merupakan daerah yang sudah sering terjadi banjir. Hal ini tidak lain karena Desa Taman Baru merupakan salah satu desa yang dialiri sungai yang semakin pesatnya pembangunan di Desa Taman Baru (Ahmad Tanwir, 2021) 
Oleh karena itu, kegiatan KKN Mahasiswa ini bertujuan untuk memperbaiki kondisi hidrologi wilayah sekitar sungai setiap Dusun di Desa Taman Baru termasuk mencegah banjir, erosi, dan melestarikan sumber daya air di Desa Taman Baru, Kecamatan Sekotong dengan melakukan penanaman bibit pohon di sekitar aliran 3 sungai di Dusun Taman Sejati, Dusun Gelumpang, Dusun Tiimbal. Kegiatan ini juga menjadi aplikasi dari Program KKN Terpadu melalui kolaborasi dengan pihak Pemerintahan Desa Taman Baru, dan beberapa komunitas lain seperti komunitas KMPB (Kelompok Masyarakat Peduli Bencana) Desa Taman Baru.

\section{Metode}

Khalayak sasaran dari kegiatan ini adalah masyarakat Desa Taman Baru, Kecamatan Sekotong yang terdiri atas 10 dusun dan 3 dusun yang terdampak, yaitu Dusun Timbal, Dusun Gelumpang, dan Dusun Taman Sejati. Namun hanya 3 dusun yang dilewati aliran sungai yang fokus kegiatan dilaksanakan di 3 dusun tersebut. Mahasiswa yang terlibat dalam kegiatan ini sebanyak 12 mahasiswa. Kegiatan ini juga bekerjasama dengan Pemerintah Desa setempat.

Kegiatan pengabdian masyarakat ini dilaksanakan dengan metode (1) pendampingan masyarakat dalam mendorong peningkatan partisipasi masyarakat; (2) analisis penyelesaian permasalahan dan penyusunan rencana; (3) evaluasi pelaksanaan kegiatan. Sasaran utama program ini adalah kelompok masyarakat maupun individu yang peduli tinggi terhadap lingkungan dengan tujuan memberikan motivasi bagi masyarakat lainnya. Penentuan lokasi penanaman bibit melalui koordinasi dan diskusi dengan Pemerintah Desa. Kegiatan penghijauan dilakukan pada lahan daerah sekitar sungai dan daerah rawan bencana banjir dengan menanami bibit- bibit pohon yang memiliki nilai ekonomis seperti kayu putih, gaharu, jambu mete dan matoa.

\section{Hasil dan Pembahasan}

Reboisasi (reforestation) merupakan kegiatan penanaman kembali pada lahan yang tandus dan gundul biasanya disebabkan karena ulah manusia. Reboisasi ini sangat penting dilakukan karena pohon bisa menyediakan oksigen dalam jumlah yang besar dan mampu menangkap polusi serta karbondioksia. selain itu pohon juga memiliki manfaat lainnya yaitu untuk menghindari dari abrasi dan erosi yang dapat merugikan seluruh makhluk hidup dibumi (Wikipedia, 2021).

Manan (1978), reboisasi merupakan kegiatan penghutanan kembali pada lahan yang gundul dan terdapat bekas tebangan maupun lahanlahan kosong yang ada di dalam hutan.

Kadri dkk, (1992), reboisasi meurupakan kegiatan membangun hutan kembali pada area yang telah habis, bekas tebangan maupun pada lahan kosong yang terdapat di dalam area hutan. Kegiatan reboisasi termasuk peremajaan pohon, penanaman pohon kembali serta menanam jenis pohon lainnya yang belum ada di dalam area hutan tersebut.

\section{Manfaat reboisasi}

Reboisasi merupakan salah satu bentuk kepedulian manusia terhadap alam yang perlu dilakukan karena jika tidak maka alam bisa saja menjadi rusak. Sebagai salah satu generasi muda dunia, harus memberikan aksi nyata dengan melakukan reboisasi ini. reboisasi sebenarnya tidak hanya bisa dilakukan di area hutan saja namun juga bisa dilakukan di dalam lingkungan sekitar dengan membuka lahan hijau. Manfaat protektif, manfaat pohon salah satunya juga bisa digunakan sebagai pelindung terutama untuk manusia. Pelindung di sini adalah bisa menahan angin kencang, sinar matahari secara langsung, peredam suara dan penahan debu. Manfaat lainnya adalah dapat melindungi manusia dari terjangan banjir, erosi dan tanah longsor

\section{Penanaman Pohon di Sungai Desa Taman Baru}

\section{Mekanisme Pelaksanaan Kegiatan}

Pelaksanaan kegiatan penghijauan disekitar sungai di 3 dusun secara bertahap dilaksanakan 3 kali, yaitu pada hari senin tanggal 6 november 2021, selasa 7 november, dan tanggal 8 november 2021 pada pukul 09.00 sampai selesai WIB yang bertempat di Dusun Taman Sejati, Dusun Timbal dan Dusun Gelumpang. Kegiatan ini dilaksanakan oleh peserta KKN mahasiswa bekerja sama dengan Kelompok KMPB, Pemerintah Desa, dan Masyarakat Sekitar. Program ini merupakan program kerja yang merupakan program pembenahan permasalahan yang ada di sungai khususnya di Dusun Timbal. Salah satu isi program kerja dari adalah penghijauan yang ada disekitar Sungai Desa Taman Baru. 

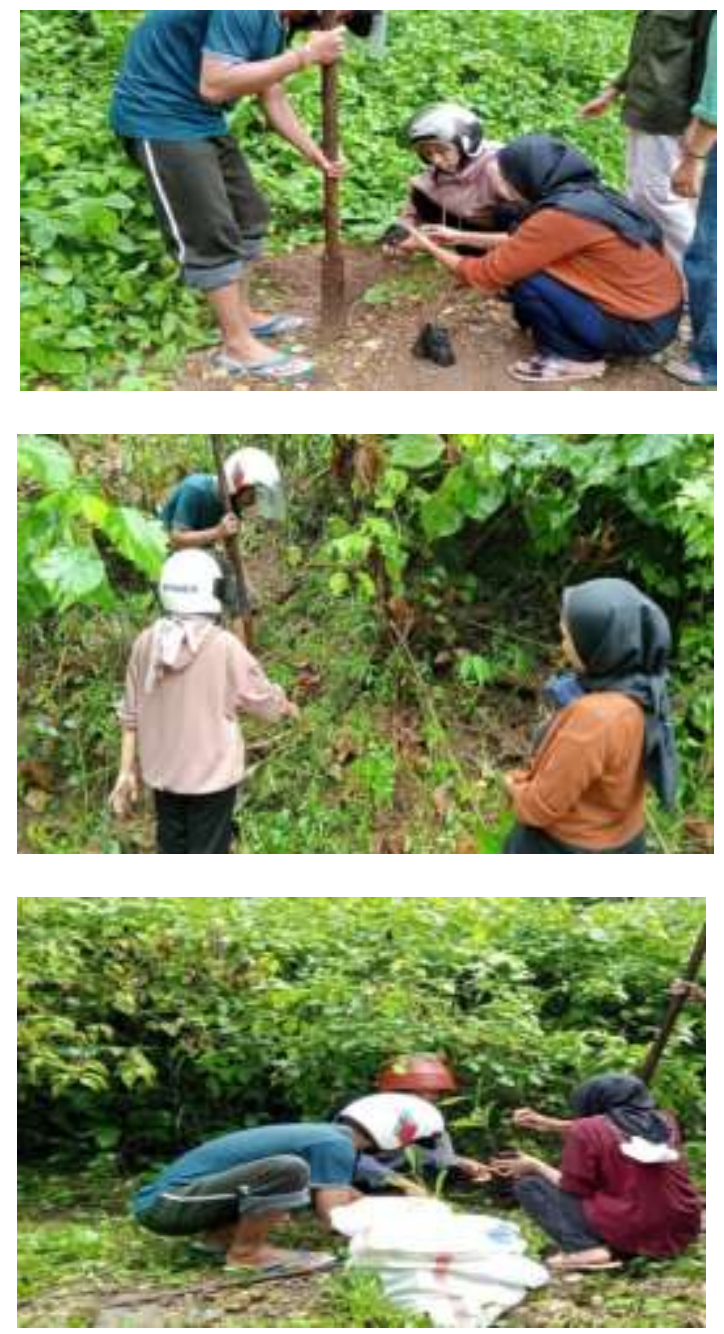

Gambar 1. Penanaman pohon di sekitar sungai Dusun Taman Sejati

Bibit yang ditanam pada kegiatan penghijauan ini antara lain bibit pohon kayu putih, matoa, jambu mete dengan jumlah total keseluruhan bibit 150 pohon. Bibit yang didapatkan dalam kegiatan ini merupakan hasil koordinasi dengan Dinas Kehutanan Kota Mataram.

Kegiatan ini diikuti oleh anggota kelompok KKN Mahasiswa Universitas Mataram dan koordinasi yang baik serta dukungan dari bapak kepala Dusun Taman Sejati turut hadir dan mendukung suksesnya kegiatan ini. Alat yang diperlukan dalam kegiatan penghijauan ini antara lain cangkul, sekop, parang, bambu, karung dan lain- lain.
Koordinasi anggota Kelompok KKN mahasiswa dengan Kepala Dusun Taman Sejati dan Kepala KMPB Desa Taman Baru

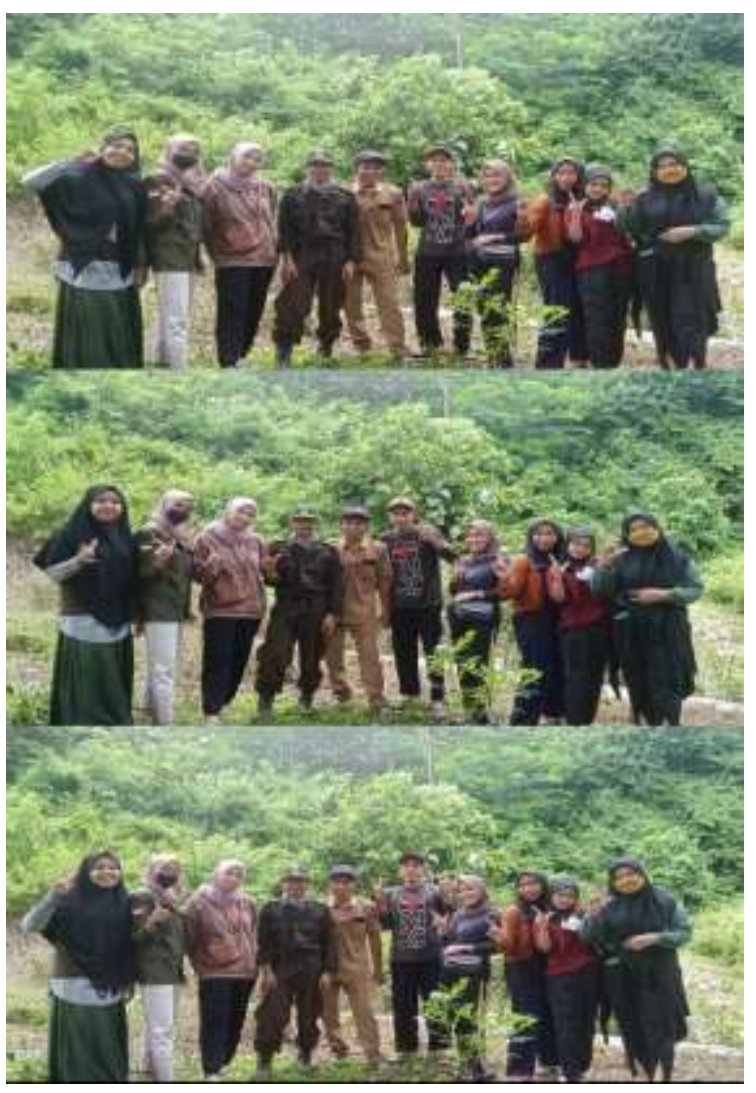

\section{Permasalahan dalam Kegiatan Pelakasanaan}

Permasalahan yang dihadapi selama kegiatan ini berlangsung adalah pertama, kurangnya koordinasi yang mengakibatkan bibit pohon diambil lebih awal dari perkiraan pengambilan sehingga kurangnya persiapan dan akomodasi yang mengakibatkan bibit pohon tersebut dikemas dengan cara yang sangat sederhana. Kedua, cuaca yang tidak mendukung di tempat pengumpulan bibit sehingga bibit tersebut banyak yang menjadi layu bahkan mati. Ketiga, medan yang masih sangat alami sehingga untuk melakukan kegiatan tanam pohon yang kedua mengalami sedikit kendala dalam akomodasi menuju tempat pelaksanaan tanam pohon serta lahan yang digunakan masih dipenuhi oleh tumbuhan- tumbuhan liar. Sehingga masih perlunya pembersihan terhadap tanaman- tanaman liar tersebut. 


\section{Solusi Terhadap Masalah}

Solusi untuk menyelesaikan permasalahan diatas pertama yaitu hendaknya dilakukan koordinasi dengan Dinas Kehutanan Lombok Barat terkait pengambilan bibit, sehingga bibit pohon yang akan digunakan untuk kegiatan tersebut masih fresh dari tempat pengambilan bibit tanpa terhalang masalah cuaca yang mengakibatkan banyak bibit yang layu bahkan mati dan menyediakan tempat khusus untuk menyimpan bibit pohon yang diambil. Kemudian perlu adanya kegiatan kontrol setiap harinya agar pohon tersebut tetap terjaga kesehatannya. Selanjutnya menambah personil yang mengikuti kegiatan tanam pohon baik adnaya ikut serta partisipasi masyarakat desa agar kegiatan tersebut dapat dilakukan secara efektif dari segi waktu dengan membagi pekerjaan untuk menanam pohon dan membersihkan tanamantanaman liar.

\section{Pembersihan Lereng Gunung Dusun Taman Sejati \\ Mekanisme Pelaksanaan Kegiatan}

Kegiatan pembersihan di lereng gunung dilakukan setelah pelaksanaan penanaman pohon di sungai Taman Sejati. Kegiatan ini dilakukan pada hari Senin tanggal 6 november 2021. Pembersihan dilakukan oleh seluruh anggota kelompok KKN mahasiswa bersama dengan masyarakat sekitar Dusun Taman Sejati, Desaa Taman Baru, Kecamatan Sekotonng, Kabupaten Lombok Barat. Kegiatan pembersiha dilakukan dengan tujuan untuk membersihkan lereng gunung dari sampah plastik serta upaya menjaga kebersihan yang digunakan sebagai jalur menyusuri lereng gunung Taman Sejati.

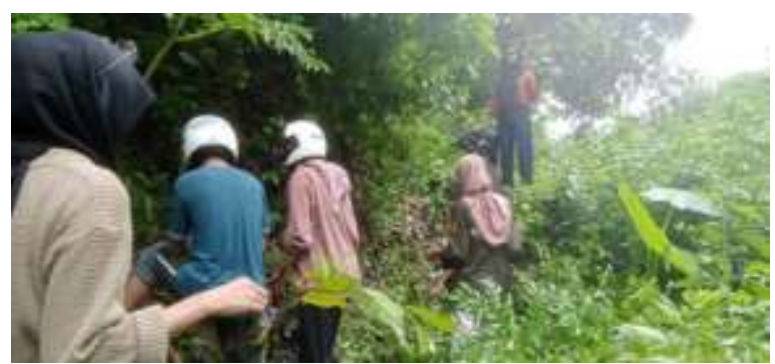

Gambar 3. Pembersihan sampah di lereng gunung Dusun Taman Sejati

Setelah penanaman pohon, seluruh anggota kelompok KKN menuju lereng gunung untuk melakukan kegiatan pembersihan seperti memungut sampah di daerah Dusun Taman Sejati dan membersihkan sampah pohon besar yang tumbang di sekitar sungai. Sampah- sampah tersebut kemudian diambil dan dimasukkan ke kantong plastik untuk dibuang ke tempat sampah. Kegiatan pembersihan ini juga merupakan bagian dari program kerja. Kegiatan ini merupakan program kerja yang berjangka panjang untuk sanitasi sungai bagian lereng gunung agar bersih, indah, asri, dan tidak adanya ditemukan penyebab wabah penyakit.

\section{Permasalahan dalam Kegiatan}

Pada saat melakukan kegiatan pembersihan terdapat beberapa masalah. Beberapa permasalahan tersebut diantaranya menuju lereng gunung yang terjal dan bebatuan yang menyebabkan kesulitan untuk menuruni lereng dan sungai. Selain itu, jalan yang licin juga membuat harus lebih berhati-hati saat melewati dan menuruni sungai Taman Sejati. Kemudian, aliran sungai yang deras juga menghambat ketika pengambilan sampah. Selain sampah plastik juga terdapat pohon besar yang tumbang, yang bisa menjadi penghalang jalur untuk menyusuri lereng gunung Taman Sejati. Dibutuhkan waktu yang cukup lama untuk mengambil pohon tersebut yang kemudian dipindahkan di pinggir sungai Taman Sejati.

\section{Solusi terhadap Masalah}

Berdasarkan permasalahan diatas terdapat alternatif solusi yang dilakukan, antara lain dilakukan gotong royong oleh anggota kelompok KKN mahasiswa dan masyarakat sekitar khususnya anggota laki- laki ketika memindahkan pohon besar ke pinggir sungai. Kemudian setelah memindahkan pohon, sampah- sampah yang disebabkan oleh dedaunan maupun ranting pohon diambil dan dibuang ke tempat sampah. Hal ini dilakukan dengan harapan jalur lereng Taman Sejati dapat dilalui dengan aman dan menjaga kebersihan jalur lereng gunung Taman Sejati. Alternatif lain yang seharusnya dilakukan yaitu mengadakan sosialisasi kepada masyarakat terhadap pentingnya menjaga kebersihan dan edukasi untuk tidak membuang sampah ke sungai yang dapat mencemari sungai.

\section{Kesimpulan}

Kegiatan pengabdian kepada masyarakat melalui program KKN mahasiswa di Desa Taman Baru, Dusun Taman Sejati, Dusun Timbal, Dusun 
Gelumpang, Kecamatan Sekotonng, Kabupaten Lombok Barat bertujuan untuk mengatasi permasalahan yang muncul di masyarakat yaitu bencana banjir, erosi dan longsor yang diakibatkan oleh kondisi wilayah yang mengalami penurunan kualitas lingkungan karena kurang terjaganya ekosistem lingkungan di sekitar sungai. Kegiatan ini merupakan bentuk aplikasi untuk meningkatkan kualitas lingkungan dan masyarakat di daerah aliran sungai dusun tersebut, salah satunya adalah dengan kegiatan bersih- bersih sungai dan penanaman pohon di sekitar aliran sungai. Kegiatan yang dilaksanakan oleh mahasiswa peserta KKN terlaksana dengan lancar karena dukungan dan koordinasi dari berbagai pihak, seperti Pemerintah Desa, KMPB Desa Taman Baru, dan Masyarakat sekitar. Ada sekitar 150 bibit pohon yang ditanam yang terdiri atas bibit pohon kayu putih, jambu mete, dan matoa.

\section{Ucapan Terima Kasih}

Terima kasih kepada Desa Taman Baru, Kecamatan Sekotong, Kabupaten Lombok Barat yang telah bersedia ditempati untuk melaksanakan program Kuliah Kerja Nyata (KKN) Universitas Mataram tahun 2021. Terima kasih kepada Dinas Kehutanan Kota Mataram yang telah menyediakan bibit pohon untuk kegiatan tanam pohon di Desa Taman Baru. Terima kasih juga kepada KMPB Desa Taman Baru yang telah memfasilitasi kegiatan reboisasi KKN di Desa Taman Baru.

\section{Daftar Pustaka}

http://aremamedia.com/torongrejo-langgananbanjir-warga-salahkan-pembangunan-dikota-batu/ "Torongrejo Langganan Banjir, Warga Salahkan Pembangunan di Kota Batu - Arema Media". [Accessed: 15-Januari2022].

http://tamanbaru.desa.id/

https://ilmugeografi.com/ilmu-sosial/pengertianreboisasi

https://malangvoice.com/musim-hujan-ini-titikrawan-bencana-di-kota-batu/. "Musim Hujan, Ini Titik Rawan Bencana di Kota Batu - MalangVoice." [Accessed: 26-Feb2020].

K. Yoshino, Y. Setiawan, and E. Shima. 2017. "Land Use Analysis using Time Series of
Vegetation Index Derived from Satellite Remote Sensing in Brantas River Watershed," J. Geomatics Plan. Vol. 4, No. 2, PP. 109-120.

LPPM UNRAM. 2020. Panduan Kuliah Kerja Nyata (KKN) Era New Normal Universitas Mataram.

M. M. Mahzum dan M. A. Mardyanto. 10 Nov 2015. "Analisis Ketersediaan Sumber Daya Air dan Upaya Konservasi Sub DAS Brantas Hulu Wilayah Kota Batu," Institut Teknologi.

S. S. Arifin, M. R. Syukri, and M. I. D. Kalamang. 2015. "Program IPTEKS bagi Wilayah (IbW) Kecamatan Kota Barat Kota Gorontalo," Gorontalo.

Szitar, M-A. Feb, 2014. "Learning about Sustainable Community Development" Procedia - Soc. Behav. Sci., vol. 116, pp. 3462-3466,

Y. Moses et al. 2019. "Zonasi kawasan berdasarkan tingkat risiko bencana tanah longsor di Kota Batu (Provinsi Jawa Timur)," Institut Teknologi Nasional Malang. 